\title{
The long genealogy of quality in the British drinking-milk sector
}

\author{
Peter J. AtKins
}

KEYWORDS: milk, quality, function, trust.

\author{
JEL CODES: I18, L66, N53, N54.
}

hroughout most of the last 150 years milk in Britain has been an example
of modernity in food production. It became a mass-produced, industrial
product, with high volume, rapid turnover, but limited choice. To modify Henry Ford's humorous dictum, you could have any kind of milk you wanted as long as it was white and about 3\% fat (Ford, 1923: 72). It is only in the last two or three decades that drinking-milk in Britain has become differentiated into the many different lines we see today: reduced fat, sweetened, flavoured, fortified, and so on. The purpose of the paper is to look at the evolution of milk quality since the late nineteenth century and to suggest that today's milk is the result of many historical developments. These include the breeding of the modern dairy cow, the changing organization of the milk industry, advances in processing technology, the identification of bacteriological risk, and the increased involvement of state-inspired regulation and the law. Until 1993 the British experience was very different from that in other countries but the regulatory framework of the European Union has encouraged convergence. It remains to be seen whether Brexit will open a new chapter in British milk quality. 


\section{La larga genealogía de la calidad en el sector de la leche líquida en Gran Bretaña}

\section{PALABRAS CLAVE: leche, calidad, función, confianza.}

\section{CÓDIGOS JEL: I18, L66, N53, N54.}

$4 \begin{aligned} & \text { lo largo de la mayor parte de los últimos } 150 \text { años, la leche ha sido en Gran } \\ & \text { Bretaña un ejemplo de modernidad en la producción de alimentos. Se convirtió } \\ & \text { en un producto industrial, fabricado en masa, con volúmenes grandes y ven- }\end{aligned}$ tas rápidas, pero escasa elección. Modificando el dicho humorístico de Henry Ford, podias tener el tipo de leche que quisieras siempre que fuera blanca y con aproximadamente un 3\% de grasa (Ford, 1923: 72). Es sólo en las últimas dos o tres décadas cuando la leche líquida ha experimentado en Gran Bretaña la diferenciación hacia las muchas lineas que vemos hoy: baja en grasa, endulzada, con sabores, enriquecida, entre otras. El propósito de este artículo es estudiar la evolución de la calidad de la leche desde finales del siglo XIX y sugerir que la leche de hoy es el resultado de numerosos desarrollos históricos. Estos incluyen la crianza de la vaca lechera moderna, la cambiante organización de la industria láctea, los avances en la tecnología de procesamiento, la identificación del riesgo bacteriológico, y la creciente participación tanto de la regulación inspirada por el Estado como de la ley. Hasta 1993, la experiencia británica fue muy diferente de la de otros países, pero el marco regulatorio de la Unión Europea ha favorecido una convergencia. Queda por ver si el Brexit abrirá un nuevo capítulo en la calidad de la leche en Gran Bretaña.

Received: 2015-12-18 - Revised: 2016-06-11 - Accepted: 2016-06-13

Peter J. Atkins [orcid.org/0000-0002-6037-6873] is Professor Emeritus at the University of Durham. Address: Department of Geography, University of Durham, DH1 3LE Durham (United Kingdom). E-mail: p.j.atkins@durham.ac.uk 


\section{INTRODUCTION}

¿Blanco y en botella, leche? It's obvious, isn't it? In the modern era milk -mainly from cowshas been used by the British with breakfast cereals and hot beverages such as tea and coffee, a simple story that is now taken for granted. Today milk is not of great of interest to most consumers; it is part of the daily routine and is rarely deemed worthy of close analysis. However, in this paper it will be argued that the image of milk has shifted, as have the definitions of its quality. In short, the milk retailed nowadays is very different from that on sale 150 years ago. It will be argued that embedded within the product we consume today is the memory of market developments over many decades (Atkins, 2007a, 2011, 2013). Michel Callon put this very well when describing what he called the economy of qualities: The product is [...] a process [...] it is [...] an object that has a life, a career (Callon, Méadel \& Rabeharisoa, 2002: 197).

First we will excavate the prehistory of British food quality, which lies squarely in nineteenth century debates about adulteration. This word implies the modification of a food by the addition of a cheap ingredient or the extraction of a valuable component, to cheat the customer and so make a profit. It is interesting to note that the alternative word in French, falsification, borrowed in many other languages, is subtly different, hinting at a pretence of quality by deception. Second, the twentieth century will be shown to have been an era of increasing complexity. In the case of milk this involved the construction of an image of quality in ways that avoided product differentiation until the 1980s. Then, third, the twenty-first century has at last shown the milk market to have potential for segmentation as never before. It will be suggested that milk quality has the potential for further development in the near term. The conclusion will reflect upon the concept of quality.

\section{THE NINETEENTH-CENTURY BEGINNINGS}

The various European food traditions value drinking-milk differently. In Britain quality has historically been thought of as a matter of composition, particularly with regard to fat, and science has played an important role in identifying and then regulating the results of any natural fluctuations. In countries such as Denmark and the Netherlands, however, where butter and cheese have been significant for export and where skim-milk was at times a residual product fed to pigs, there was an emphasis in the drinking-milk sector upon the standardization of composition to enable the legitimate extraction of some of the butter fat. Thus by the 1950 s Danish milk was standardized at 3.5\% fat and Dutch milk at $2.5 \%$ (Franklin, 1953). Later farmers in the Netherlands opted for payment by protein content as well as fat (Cook, 1960: 119). 
A third group of countries belongs to what we might call the wine tradition of food quality. In France, Italy and Spain, for instance, there was familiarity with the seemingly infinite variations of grapes, vintage, terroir, and vintners' processes of production, not to mention quality claims-making by wine merchants. The resulting mentality has therefore been different from that in the narrow northern European world of milk and beer. As a result, in France it seemed natural to turn to administrative definitions and legally enforceable norms as means of preventing chaotic market conditions. Other southern European food cultures and legal systems followed suit and in the twentieth century this approach was extended beyond wine to a wide range of other foods, including drinking-milk and manufactured dairy products. One outcome, the French concept of Appellations d'Origine Contrôlées, has proved to be so attractive that it has become the basis for the European Union to attach official certification to place-based notions of quality, including for cheese and butter.

By contrast, in Britain the top-down imposition of quality norms has always been problematic. One reason is that the political culture has tended to be suspicious of bureaucratic systems but even more important is the common law legal tradition that operates by judicial precedent rather than regulation by the state (Atkins, 2010: ch. 8). We will explore this later in the paper.

Why else was Britain different right through to the 1990s? There seem to have been several related factors. One was that the rapid urbanization of the nineteenth century and the related industrial and commercially-based prosperity created one of Europe's first large-scale markets for drinking-milk. To begin with the supply was local, from the many cowsheds that occupied interstices in the urban fabric (Atkins, 1977). But these came under the scrutiny of the sanitary movement and eventually under inspection by local authorities eager to reduce smells and pollution from heaps of manure. Even with the advent of railway transport from the distant countryside from the $1850 \mathrm{~s}$ and $60 \mathrm{~s}$, demand eventually outstripped the ability of the industry to provide enough fairly priced, clean and genuine milk. Adding water to stretch the amount of milk available and chemical preservatives to lengthen its shelf-life therefore became serious problems in the second half of the century. According to one estimate, about $25 \%$ of the average pint of milk in the 1870s was added water (Atkins, 1991).

Detecting food frauds required the laboratory-based application of physics and organic chemistry. As a result, in Britain adulterators of milk were brought to book under a series of Sale of Food and Drugs Acts that started in 1860. The irony was that many innocent farmers were also prosecuted before anyone thought to establish a legal definition of the real thing. This came in 1901 with the Sale of Milk Regulations, which in effect clai- 
med that science could determine nature's intentions. "Natural" cow's milk was said to contain $3.0 \%$ of butter fat, for instance, and a milk that was more watery than this was presumed to have been fraudulently manipulated.

Problem solved? Well no, because what happened if cattle were fed on very watery grass or silage? The milk they produced would be as it came from the cow, nothing added and nothing taken away but it would still be of a low "quality" fat-wise. Legal challenges in the British courts in the early twentieth century proved that almost any milk coming from a healthy cow was acceptable, as long as it was not modified later (Atkins, 2010). Here science and the law combined to say definitively what was natural.

In all of this, whose expertise counted? On one hand, there were the traders with their organoleptic skills. On the other, the "objective" expertise of laboratory science came increasingly to the fore, although knowledge remained fragmented and contested. Government scientists frequently disputed the analyses of their local authority colleagues and there was conflict about scientific expertise for several decades towards the end of the nineteenth century.

Building a scientific consensus about "genuine" milk and about the methods of detecting fraud eventually came in the early twentieth century, the role of industrial food chemistry being decisive. The large dairy companies and, later, other food processors and manufacturers invested in testing that was quick, efficient, and of a low unit cost. The knowledge generated by their standardized laboratory protocols enabled such companies to establish technologies of trust in controversial areas. As a result, although the number of analytical samples increased, the proportion found to be adulterated decreased.

The three conclusions from this account of milk adulteration are, first, that milk quality depends upon the technologies of measurement and enforcement and, second, that legal and administrative measures to enforce fairness and genuineness, because they are assembled over long periods through trial and error, inevitably have a momentum that reflexively acts as a conceptual filter for notions of quality. Third, a further consequence was the gradual emergence of an understanding of "responsibility" for quality. This was initially ignored by small retailers but later emerged out of contractual arrangements between the various parties in the milk chain (see Section 3.6). Eventually quality became a selling point but even then the interests of the consumer were a priority only at the premium end of the market. 


\section{TWENTIETH-CENTURY DIMENSIONS OF QUALITY}

In the twentieth century the subject of food quality became highly complex. We will look at three dimensions: function, aesthetics and trust, with the emphasis principally upon the last of these. Many more categories of quality are discussed in the literature (Grunert, 2005).

In the case of drinking-milk, function refers to how it is used and whether at that level it meets the requirements of the consumer. For instance, sour milk is dysfunctional for most purposes in Britain, although it is popular in Eastern Europe and is manufactured there using bacterial fermentation. Function also includes both the health-giving properties that we associate with natural foods and the occasional alerts about the diseases that can be spread by milk. Also the detrimental effects of its fat content revealed in the last few decades have presented another type of challenge to milk's assumed positive functionality.

Aesthetics may refer to the image of a foodstuff, which is a powerful means of enhancing its perceived quality, but there is of course also its immediate sensory attributes: appearance, touch, smell, taste, mouth-feel. Here the whiteness of milk has always had symbolic significance, but quality may also be judged by its richness indicated by a yellowish tinge and a clear cream line when not homogenized.

Trust is more the responsibility of the suppliers and is bound up with the claims they make for their product. Over a period if they reliably keep their promises they may be able to build up trust with the consumer but there are other ways, for instance by the provision of information on labels or through brands. In the case of milk, as we have seen, adulteration seriously undermined system trust, a problem that lasted for decades. Trust may be recovered by the deployment of third party expertise, such as that vested in public analysts, or by various forms of certification.

\subsection{Health and food safety}

The health consequences of milk consumption were sometimes worse than the risk of being cheated. One example is that in the last two decades of the nineteenth century cow's milk was increasingly used for infant feeding. There is some evidence that this was in response to a decline in breast-feeding and, in the absence of a complete understanding of infant nutrition, the result was at times disastrous (Atkins, 2003, 2017). The milk used was often contaminated with faecal material and dirt from the cowshed but, in addition, 


\section{TABLE 1}

The main pre-Second World War arguments against milk pasteurization

\section{Sanitation}

- Pasteurization may be used to mask low-quality or stale milk.

- Pasteurization is an excuse for the sale of dirty milk and discourages the efforts to produce clean milk.

\section{Nutrition}

- Pasteurized milk has a cooked flavour and is less palatable.

- Pasteurization diminishes the nutritive value of milk -reduces vitamins (e.g. vitamin C) and minerals (e.g. calcium) made unavailable.

- Pasteurization destroys beneficent enzymes, antibodies, and hormones.

\section{Physical and Bacteriological Quality}

- Pasteurization reduces the cream line.

- Cheese is better when made with unpasteurized milk.

- Pasteurization destroys the healthy lactic acid bacteria in milk, and pasteurized milk goes putrid instead of sour.

- Pasteurization kills the bacilli in milk and leaves them to decompose when exposed to the air.

\section{Public Health and Safety}

- Pasteurization is often inefficient and imperfectly pasteurized milk is worse than raw milk.

- Pasteurization, by eliminating tuberculosis of bovine origin in early life, leads to an increase in pulmonary tuberculosis in adults.

- Pasteurization is unnecessary, because raw milk does not give rise to tuberculosis.

- Pasteurization would reduce the incentive to eradicate disease in cattle.

- Pasteurization produces scurvy and rickets.

- Pasteurization reduces the fertility of animals fed on it and might lower the human birth-rate. The shadow of depopulation and national decline is looming in the near future.

- The medical profession is not unanimous in support of pasteurization.

\section{Economics}

- Pasteurization will increase the price of milk.

- Small dealers will have to buy pasteurizing apparatus or go out of business.

- In rural communities the quantities of milk sold are so small that pasteurization is impractical and, anyway, milk goes directly and promptly from producer to consumer.

Source: modified from Atkins (2016). 
milk was also a medium for the spread of infectious diseases. In the case of heightened infantile mortality at the end of the nineteenth century this was most often attributed to so-called summer diarrhoea.

The second health challenge of milk consumption was the risk of catching the zoonotic disease, bovine tuberculosis (Atkins, 1992, 2000a, 2008; Waddington, 2005). This is caused by a mycobacterium that is able to thrive in the bodies of both cattle and humans. My estimate is that at least 800,000 deaths were caused in Great Britain by this infection in the period 1850 to 1960 (Atkins, 2016). Eventually pasteurization solved this problem by bringing the milk to a temperature above the thermal death point of the $\mathrm{Myco-}$ bacterium bovis.

Intriguingly, not everyone was in favour of pasteurization (Atkins, 2000b). In the period before the Second World War in particular there was vociferous opposition to the heat treatment of milk from a variety of groups. As Table 1 shows, the anti-pasteurization arguments were many and seem to have centred around the loss of milk's health-giving constituents, such as vitamins, which had only been discovered in the first decade of the twentieth century. There were other points, such as removing any incentive for farmers to produce clean and disease-free milk, and objections from vitalists and eugenicists who thought that heat would destroy the "life" in milk and so affect the nation's health and vigour. In the 1920s most of London's milk was pasteurized, largely as a way for dealers to extend its shelf-life and it was not until after the Second World War that the rest of the country shared in this technological revolution. The vast majority of milk was heat-treated by the 1950s and the risk of bovine tuberculosis spreading from infected cattle to humans was finally declared to have been eliminated in 1960 .

The bacteriological contamination of milk continues right up to the present. On the farm the most likely sources continue to be a) infection in the interior of the teats; b) poor hygiene in the cowshed (contamination from faeces, bedding, soil, feed); and c) surfaces of the milking equipment (Vissers \& Driehuis, 2009). In the British dairy herd mastitis is an ongoing problem (Table 2) correlated with the presence of Staphylococcus aureus in bulk milk and potentially having food safety implications. The Milk Marketing Board began an experimental scheme measuring hygienic quality in 1962 and from 1971 they commenced commercial testing for mastitis in 1971, followed by free national testing in $1977^{1}$. The table shows somatic cell counting and Bactoscan screening, two methods of monitoring the context of mastitis.

1. The Milk Marketing Board was a producer monopoly that was inaugurated in 1933. 
TABLE 2

England and Wales: drinking milk hygiene monitoring ('000 per ml)

\begin{tabular}{ccc}
\hline & Bactoscan & Cell count \\
1977 & - & 464 \\
1990 & - & 322 \\
2000 & - & 191 \\
2005 & 33 & 193 \\
2014 & 26 & 167 \\
\hline
\end{tabular}

Source: Milk Marketing Board; Department for the Environment, Food and Rural Affairs; Sumner (2010).

Third, a feature of milk quality discussion in the last 30 years has been the presence of traces of the antibiotics used by famers to manage infections in their livestock and promote growth. In intensive systems such as used in the dairy industries in Britain and Germany, this has reached proportions that can be called contamination because of the longterm risk that they pose to human health (Kirchhelle, 2016). Exposure to a spectrum of antibiotics over an extended period is said to enhance the possibility of resistant strains of bacteria emerging, potentially one of the most serious public health hazards of our times (Podolsky, 2014). Although not yet an issue in the public mind, a report commissioned by the Prime Minister looks likely to lead to a legislative tightening of farming practice (O’Neill, 2015). In theory the milk of any cow under treatment must be withheld until the chemical residues have cleared, though the financial incentives to flout this are clear, especially since the onus for testing is placed on the wholesale purchaser of milk rather than the farmer.

A fourth dimension of drinking milk has had a major impact upon consumer demand in terms of total quantity and also upon the composition of that milk. Following the work of Ancel Keys in America and the guidelines issued by the US Department of Agriculture in 1980, high fat milk was linked to heart disease. As a result, across the Global North there has been a switch away from saturated fats and this has affected consumers' appetite for dairy products. In the case of Britain a new product, semi-skimmed milk, was launched in 1981 and quickly captured a significant part of the drinking-milk market.

\subsection{Cattle breeding}

Cattle breeding over the past 200 years has had an effect on the volume and composition of milk produced in Britain. The shorthorn was the prominent breed in the nineteenth century because of its profitability as a dual-purpose animal. Its milk yield was good and there were many substantial cuts of meat in its large carcase. So successful were they 
in fact that shorthorns were exported all over the world, especially to British colonies where settlers attempted to reproduce a dairy economy similar to that in the homeland. In the second half of the nineteenth century, as milk production became the principal goal of dairying, other breeds were considered. The Dutch or generic black and white cows that had been popular with London cowkeepers for decades gradually spread in the second half of the nineteenth century, particularly with the import of new blood from the $\mathrm{Ne}$ therlands. The need was for cows producing milk of a stable and reliable quality and this was eventually delivered by the efforts of the British Holstein Cattle Society, founded in 1909 and later renamed the British Friesian Cattle Society. By 1947 Friesians were 20\% of the national herd, rising to $76 \%$ in 1970 , whereas shorthorns fell from $85 \%$ in 1908 to only 3\% in 1970 (British Friesian Cattle Society, 1930; Stanford, 1956). This genetic revolution affected the compositional quality of market milk, as can be seen in Table 3 . If milk solids are a definition of milk quality then breeding certainly had an impact in the twentieth century. The point here is that breeders and farmers were increasingly using cows with milk that was high in volume but watery, just above the legally enforceable compositional standards. In other words a combination of law and breeding science had an impact upon a milk quality that, as a result, was different in Britain from other countries.

TABLE 3

Percentage weighted average composition of milk, England (1926-50)

\begin{tabular}{lcc}
\hline & Butter fat & Solids-non-fat \\
\hline $1926-30$ & 3.70 & 8.83 \\
$1931-35$ & 3.67 & 8.81 \\
$1936-40$ & 3.65 & 8.79 \\
$1941-45$ & 3.64 & 8.76 \\
$1946-50$ & 3.62 & 8.74 \\
\hline
\end{tabular}

Source: Cook (1960: 164).

\subsection{Technology}

The keeping quality of milk was a major issue for the trade in the century before the Second World War. Milk contaminated with dirt and dust was unlikely to last long in a fresh state because of its bacteriological load. But even clean milk was at risk of souring because of the slow and complex transport arrangements mentioned above. In hot weather this meant that consumers often received their milk in a deteriorated condition.

A priority for most cowkeepers was to cool their milk as quickly as possible. Technologies gradually became available, the first of which was the Lawrence capillary refrige- 
rator, which was introduced in a small way in 1872 . This British cooler, as it was sometimes called, was such a simple yet effective design that it remained the farm industry standard until the 1960s when temperature-controlled bulk tanks took over.

One problem was that the early water-tube surface coolers used well or mains water, which was rarely cold enough, and at times in summer was over $15^{\circ} \mathrm{C}$ (Cameron Brown, 1936). Another was the serious risk of infection if they were not kept clean. The alternatives were expensive. By 1950 the majority of farmers were cooling their milk in one way or another. The alternatives at that date were: surface coolers; brine coolers (from the 1890s); direct expansion coolers; plate heat exchangers (factories only); churn immersion coolers; spray coolers; and coil immersion coolers.

The Milk and Dairies Order (1926) required the cooling of milk to within $2.7^{\circ} \mathrm{C}$ of any water available on the farm, and from the mid-1930s Milk Marketing Board contracts required cooling to $15^{\circ} \mathrm{C}$. But many farms lacked a mains water supply and had to rely on well water, rainwater, or surface supplies in ponds or streams. Several official reports pointed this out in the 1930s and 60\% of farms were said in the wartime National Farm Survey to have been hampered by this problem.

Apart from the cosmetic aspect of milk, chemicals were also added to keep it "sweet" as long as possible. The earliest record of this is from Paris in the 1820 s, where bicarbonate of soda was used to neutralize the lactic acid which powered the souring process (Barruel, 1829). In mid-nineteenth century Britain such "preservatives" came to be regarded as essential in a market increasingly dominated from the 1860 s by distance and speed because they delayed the process of decomposition (Atkins, 1991). The supply of milk to a rapidly urbanizing society meant drawing on farms from further and further afield. The urban cowsheds which had once been dominant were unable to meet the surge in demand and it was necessary to push the "milkshed" outwards, at first to dozens, and later to hundreds of kilometres. This acceleration was facilitated by the railways and by the addition to the milk of chemical "preservatives".

Dairymen seem to have experimented widely, with compounds based on borax and/or boric acid gaining many adherents. Over $40 \%$ of the samples examined from 1893 to 1898 by one researcher contained some boric acid (Clayton, 1899), as did $27 \%$ of the milk analysed in Islington in 1899 (Harris, 1899). In evidence to a parliamentary committee investigating the use of preservatives in food, it was estimated that about half of London dairymen used one or more compounds, and the same committee heard evidence that the milk trade as it is at present [...] cannot be carried on without the use of preservatives (Maxwell, 1902: Q.3928). 
These chemicals, although they inhibited the visible souring of milk, killed microbes only selectively and therefore may have lulled the unsuspecting consumer into a false sense of security. The physiological effects of treated milk were not clear at first. The first medical article on the subject was published in the Lancet in January 1877. Later there was evidence of the injurious effect of salicylic acid, and claims that boric acid exacerbated diarrhoea in infants, especially when the milk was heavily impregnated with the chemical (Maxwell, 1902).

Parliamentary committees in 1896 and 1901 recommended that preservatives should be banned, and the Local Government Board issued a circular to Local Authorities in July 1906 suggesting action under section 6 of the Food and Drugs Act (1875), which forbade the sale to the prejudice of the purchaser of any article [...] which is not of the nature, substance, and quality demanded (Atkins, 2010). Formal action was delayed, however, until the Public Health (Milk and Cream) Regulations of $1912^{2}$.

As we saw above, pasteurization was the other twentieth century technological development that greatly affected milk quality. It was contested at every stage and bitterly so in Britain up to the Second World War. At first it was an alternative to chemical preservatives and was used principally by dealers who wanted to extend the shelf life of their milk. Most did not declare the heat treatment to their customers for fear of losing business.

\subsection{Organization of the milk industry}

The intense urbanization of the industrial revolution in eighteenth and nineteenth century Britain was focused a) in the coalfields on the Midlands and north of England, south Wales, and the central belt of Scotland, and b) in the south east of England around London. None of these locations coincided with the specialist dairying areas and milk therefore had to be transported over long distances to satisfy demand. In the case of London, by far the largest market for drinking-milk, these distances in 1900 averaged $225 \mathrm{~km}$ and took about five and a half hours by railway.

Special railway wagons and timetable slots for milk trains had to be provided in order to move the milk quickly and to prevent deterioration (Atkins, 1978). The every-day, repetitive and complex nature of the milk trade was a challenge for the railway companies. The early designs of milk cans were not satisfactory since dust and dirt were able to get

2. Made under the Food and Drugs (Adulteration) Act 1928. 
in and there was also scope for unscrupulous rail staff and wholesalers at the receiving station to add water. From the mid-1920s this problem was solved by the introduction of rail and road tankers large enough to contain the milk of thousands of cows. These tankers were glass-lined for ease of cleaning and cork-insulated to maintain a steady temperature, but their introduction also caused a problem. It took the milk of only one diseased cow to infect a whole tanker of milk with tuberculosis, for instance. On the other hand, the composition of bulk milk was less likely to fall under the government guidelines because it represented the average of a particular district rather than the milk of an individual farm, as had been the case with single cans. Farmers began installing their own bulk milk tanks in 1956 and in the 1970s the collection of cans of milk by the Milk Marketing Board was finally phased out.

The wholesale and retail milk trades gradually evolved to lubricate the various articulations that joined the distant farmer to the daily doorstep delivery (Atkins, 1978). In the nineteenth century the milk walk using a yoke and pails was replaced by a horse-drawn cart or float and the milk perambulator, generally dispensed from a churn into the householder's jug, therefore risking casual contamination (Atkins, 1980). In many cities there were two or three deliveries per day, with the result that customers were drinking unmixed milk from the morning or evening milkings, with obvious consequences for variations in quality. The early twentieth century introduction of bulk transport, bulk processing, heat treatment and bottling all changed this completely. Drinking-milk became safer and more standardized in quality.

It was in the 1860s that the first large dairy companies emerged, with the organizational capacity to attract supplies railed from former butter and cheese producers. Express Dairies expanded the London trade at this time under the tutelage of George Barham (Atkins, 1984). There were substantial profits to be made and in 1915 the highly capitalised United Dairies was formed as a merger of wholesale and retail companies. The Combine as they came to be known grew further in the 1920s and attracted criticism for their "unfair" competitive tactics. At this time the numbers of small producer-retailers declined and, as a result, there was a significant reduction in the variability of composition and of quality. The large dairy companies were able to invest in bottling and pasteurization plant and they also had their own laboratories to monitor milk quality on an industrial scale. It is important to note that much of what was known about milk in the early twentieth century was the result of their activities, not academic research or sampling by local authorities.

The Milk Marketing Board was a peculiarly British solution to the global economic uncertainty of the 1920s and 1930s. As a result of cheap imports of cheese and butter, 
many British farmers had begun to produce milk. There was an oversupply of drinkingmilk and both prices and quality were so unsettled that the government considered stepping in. The solution was the provision of a corporate alternative to cut throat capitalism. The Milk Marketing Board of England and Wales was formed in 1933 and a new Milk Marketing Scheme inaugurated the following year. This was to be run in effect by the farmers through the organizational capacity of the National Farmers' Union, a very different situation from the previously wholesale dealer-dominated market.

In 1935 the Board initiated a new grade of Accredited Milk aiming for cleanliness, paying farmers $1 \mathrm{~d}$ per gallon to join. To qualify farmers had to submit their herds to six monthly veterinary inspections, with the removal of any tuberculous cattle. In addition, their milk was tested at least three times a year and had to have less than 200,000 bacteria per cubic centimeter, and E. coli absent in $1 / 100$ cubic centimeter ${ }^{3}$. Although drinking-milk quality was never its raison d'être, the Milk Marketing Board also supported research on clean milk and its contracts required certain improvements by famers, for instance the cooling of milk. Improvements in bacteriological and other aspects of quality were achievements of the Board and its suppliers but after six decades it was looking increasingly eccentric to the principles of the EU project, especially the introduction of the Single Market in 1993. In 1994 the British government could no longer justify a farmerled monopoly and the Board was abolished. Milk quality now became the responsibility of contractual arrangements between private dairy companies and their suppliers, backed up by the investigatory powers of the Veterinary Laboratories Agency and the Food Standards Agency. The quality data were published from 1943 to 1997 by the Milk Marketing Board and at the latter date the National Milk Records then was also privatised. The historic trend in quality has been one of gradual improvement.

A final aspect of trade organization was the collective and individual efforts to boost the image of drinking milk and encourage consumption. The National Milk Publicity Campaign began in a small way in the 1920 s funded by dairy companies. Its mass poster and newspaper advertising, followed after the War by the use of television, were important in mitigating the negatives in the public mind, such as the dirt, disease and adulterants previously thought to be common in milk. But another of the National Milk Publicity Campaign's successes was its pioneering of school milk in the 1920s and early 1930s, establishing a system of distribution that worked and which encouraged government to adopt it as a nationwide policy in 1934 (Atkins, 2005). This created an imme-

3. It was not until 1957 that wholesale payments to farmers producing poor milk were reduced if they were unable/unwilling to make the necessary improvements. 
diate increase in the drinking-milk market and in the long term there were many more habituated consumers.

\subsection{The state and milk grading}

Conditions of milk production in Victorian and Edwardian Britain were poor. Manure and other dirt from the cowshed was routinely present in retail drinking-milk. In Manchester in 1896 , for instance, only $4.2 \%$ of samples collected were rated as "clean" and the average load of dirt was 256.7 parts per million (Delépine, 1910). There was a lot of resistance from cowkeepers to sanitary improvements, which were said to be a doctor's fad. Improvements therefore had to be made compulsory. The Dairies, Cowsheds and Milkshops Orders of 1879, 1885 and 1899 gave progressive local authorities the powers they needed to close offending urban cowsheds or at least to require improvements that would undermine their profitability. Contamination also took place en route to market, in retail dairies, and especially in those slum houses where storage facilities were meagre.

Following precedents set in America in the 1890s, the concept of clean milk eventually spread to Britain (Atkins, 2007b). In the 1920s an academic interest in clean milk began at the National Institute for Research in Dairying, based at the University of Reading. Here the practical steps needed to reduce the contamination of milk were tested and then best practice was spread to the farming industry through the demonstration effect of clean milk competitions. This was paralleled by the advocacy of the National Clean Milk Society (1915-28), which organized lectures and published pamphlets on the subject. Through the connections of its organizers this Society was influential in policy-making circles and played a part in establishing the idea of certifying or grading milk. The wartime Milk (Special Designation) Order (1917) began this in a small way and was followed by the Milk and Dairies (Amendment) Orders in 1922 and 1923, which introduced five grades. These were based upon criteria such as freedom from bovine tuberculosis, the number of bacteria, and whether the milk was bottled and pasteurized. The proportion of milk that was graded in this way was very small to begin with and the grades were difficult for consumers to understand but gradually the demand increased and at the premium prices charged the trade began to realise that there was money to be made in improving the quality of their product.

In 1942 under difficult wartime conditions a National Milk Testing and Advisory Scheme began, operated by the Ministry of Agriculture. After the war in 1948 a Joint Milk Quality Control Committee became important for ideas about improvements and how they might be enforced. In 1949 the Milk (Special Designations) Act insisted for the first 
time that all milk had to be graded. By 1954 there were only three categories: tuberculin tested raw milk, which came from herds attested free from tuberculosis; pasteurized milk, which had to be sold in bottles; and sterilized milk. Once the national herd was declared free from tuberculosis, there was no further need for the tuberculin tested designation from 1963, but technical advances enabled a new one of ultra heat treated milk in 1965.

From October 1982 a new test for the hygienic quality of milk was adopted, the Total Bacterial Count or Standard Plate Count, using a 72 hour incubation at $30^{\circ} \mathrm{C}$ and expressed as colonies per millilitre of milk $^{4}$. This seldom exceeds 10,000 per millilitre in healthy cows kept under hygienic conditions. Nowadays the cooling of milk to $4.5^{\circ} \mathrm{C}$ is a contractual requirement in Britain but this may delay bacterial growth for only a day or so if the initial loading is high. In 1985 the Health and Hygiene Directive (85/397/EEC) set out Europe-wide standards, and these were replaced shortly after in Directive 92/46/EEC, as enacted in Britain in the Dairy Products (Hygiene) Regulations (1995). The present limit for the plate count is 100,000 colonies per millilitre at $30^{\circ} \mathrm{C}$ in milk intended for pasteurization or 50,000 if it is to be consumed raw. Another quality measure is the presence of mastitis in dairy herds, which has serious economic consequences for the farmer and can cause illness in humans. The current maximum for this is 400,000 somatic cells per millilitre. Finally, there are also measures for a range of other issues, such as antibiotic residues and the presence of Staphylococcus aureus, and creameries also monitor the presence of a number of minor infectious diseases that are dangerous for humans.

\subsection{Law and regulation: the history}

Trust is an important aspect of quality, for any foodstuff. The point is that the consumer needs to feel that the product meets their requirements, not just for the immediate moment of consumption but also for the term of repeat purchases. This perception was particularly challenged during the era of gross adulteration in the nineteenth century but arguably it is just as relevant now because many of us have particular preferences in terms, for instance, of price, chemical additives, healthiness of ingredients, and the ethical context within which food is produced and traded.

In the past the trustworthiness of weights and measures was a key issue in judging the honesty of traders but now our concerns are more about the claims made on labels and in advertising. Warranties, trademarks, trade names and various forms of certification re-

4. Bactoscan, an automated measurement technique, has now replaced the Total Bacterial Count method in most dairies. 
main important but the all-embracing concept of brand has become a conceptual thumbnail symbolizing trust and the possibility of association with an ideology or lifestyle. Brands are now so fundamental that we can say that they have become an important building block of modern capitalism and lifestyles.

Warranties between farmers and milk wholesalers were common after the Food and Drugs Act (1875) made them a form of defence for the receiver. In other words the warranty concept established in law that responsibility for quality could be traced to the issuer and therefore introduced a notion of agency in the food chain. For drinking-milk this was significant because of the many transactions that took place every day without there necessarily being paperwork attached to each milk can. Warranty was sometimes an oral statement or maybe a six-monthly written clause in a contract. Further than this, we can assert that the development of warranty was the first step towards a networked concept of quality, in other words that several agents in relationship had shared responsibility. Hitherto prosecutions for adulteration in England and Wales had been mainly of retailers and mens rea, or guilty knowledge, on their part was not necessary for a conviction. Their only effective defence was in the law of contracts.

The law of contracts was a development of the common law, a characteristically Anglo-Saxon legal context that proceeds by historical precedent rather than by centralised law-giving, by code or by decree as is common in the rest of Europe. It was not until the Sale of Goods Act (1893) that there was the first top-down attempt to rewrite the common law of contracts. The rights of the buyer were now to be enhanced through the technical device of an implied warranty of merchantability.

Warranties became especially common after the Food and Drugs Act of 1899 and remained so until the Food and Drugs Act (1938). But in 1922 a parliamentary committee found the warranty system to be failing once more. By then the mixing of milks had become commonplace and identifying those responsible for fraud had become more difficult as a result: after milk from two sources or more has been mixed, the separate warranties can no longer avail (Mackenzie, 1922: 889-90). The 1928 Food and Drugs (Adulteration) Act allowed a warranty defence only if a sample had been taken from unmixed milk, and if notice was given to the local authority within sixty hours of the sample being taken. Churns had to be labelled with the names and addresses of the consignor and consignee, and have a statement about it being pure and unadulterated new milk. 


\subsection{European regulation}

As we have seen, Britain's membership of the European Union has been important in establishing new frameworks for marketing and milk grading. In addition, the understanding of quality has been forced to change to the EU legal definitions in terms of a) composition, and b) hygiene and food safety. Based on Regulation 1411/71, later amended as Regulation 2597/97 (Hickey, 2009), drinking-milk could be raw, non-standardised whole, standardised whole, semi-skimmed or skimmed. In the whole milks the fat has to be a minimum of $3.5 \%$, the protein $2.9 \%$, and non-fat dry matter $8.5 \%$. In semi-skimmed milk the fat is $1.5-1.8 \%$ and $<0.5 \%$ in skimmed. British dairy processors immediately began to take advantage of standardisation but it was not until the Drinking Milk Regulations of 2008 that milk could be labelled with various fat levels. Now British supermarkets have an astonishing range of "milk". In addition to flavoured or filtered or fortified milk, there is milk with $0.1 \%, 1 \%, 2 \%$ and $4 \%$ fat, and the consumer in England and Wales -but not Scotland- can also choose between raw milk and heated treated milks that have been pasteurized, sterilized or ultra heat-treated.

An EU hygiene standard was not agreed until Directive 85/397, as noted above, supplemented by Directive 92/46 and since then there have been many further regulatory developments taking into account technological advance and coordination with other international organizations such as the Codex Alimentarius and the Office International des Epizooties. As a result of harmonization with other EU countries, the constituent nations of the United Kingdom have incorporated these standards into their own Drinking Milk Regulations and Food Safety and Hygiene Regulations. The scope for derogation is limited and drinking milk quality has therefore become a European concept.

As a result of this Europeanization of milk quality, there has been greater change to consumer perceptions in the last 20 years than in the previous 200. The Continental understanding of milk as a substance that could be manipulated and standardized in its composition was embraced and fundamental British understandings of "natural" quality quickly passed into history. Nevertheless some differences remain. Ultra heat-treated milk, which has an extended shelf life of six to nine months, is popular in countries such as France, Belgium, Spain and Portugal, but has almost no traction in the British market. This is a continuation of a preference for fresh milk dating back more than 150 years, contrasting with the Continental practice of boiling milk to reduce the risk of disease (Atkins, 2010). 


\section{THE TWENTY-FIRST CENTURY}

The new Europeanized constructions of quality surrounding drinking milk came partly to be understood in terms of the supposed health premium of a lower fat content but there are other claims. Filtered and ultra-filtered milk in particular is said to be purer, with a fresher taste. Also a broad spectrum of bacteria is removed, reducing the risk of disease and prolonging its shelf life. Arla's Cravendale brand of filtered milk is supported by an advertising campaign in which its milk drinkers are said to be connoisseurs ${ }^{5}$.

Despite these marketing tactics, in the five years 2009-14 both the quantity and the value of cow's drinking-milk fell in Britain (Mintel, 2014). This was partly due to a reduction in the consumption of tea and breakfast cereals, the traditional accompaniment of milk, and despite a rise in coffee sales of over $20 \%$. Another factor has been the availability of "alternatives". One driver has been the number of people who say that they are allergic to cow's milk, some of them turning to goat's milk, which is up $25 \%$ in the same period, and to hypoallergenics such donkey and camel milk. But non-dairy alternatives are also flourishing. The market for soya "milk" is up by $14 \%$, especially in the $16-34$ age group and many other plant-based products are now available: soya, almond, coconut, oat, hazelnut, rice, cashew, spelt and quinoa.

It is not necessary to move from cow's milk to find a greatly increased range of choice. Flavoured milk now represents an astonishing $9 \%$ of the total, although one wonders whether this growth will continue given current concerns about added sugar. Lactose-free milk is now marketed by several companies, along with milk fortified with selenium, or protein, calcium, iron or various vitamins. Recognising that consumers are increasingly environmentally-aware, dairy companies are now going beyond the familiar claim of organic production, to promises that their milk is from free range dairy pasture or from cows fed on wholesome diets that reduce the saturated fats in their milk. There is also milk with an ethical twist, similar to fair trade, that involves higher payments to farmers in return for quality.

A likely further set of changes are in terms of palate. In view of the suggestion that plastic containers impart a chemical taste and that pasteurization also alters flavour, it seems likely that the marketing of milk will eventually make an effort to emulate wine ${ }^{6}$. There are already claims that milk from a single breed of cow might enhance quality, without

5. https://www.facebook.com/Cravendale/videos/10153196956210236/

6. But many consumers prefer the taste of pasteurized milk to that of raw milk because the latter has an animal smell (BOPPANNA, 2007). 
the milk being homogenized, and the next step is perhaps to link it to the terroir of high quality pastures. Whichever way this trend goes, there is room at the top end of the market for high quality premium milk.

Despite the obvious health risks, a small trade in raw milk continued at the end of the twentieth century in England and Wales for those who made a conscious decision to seek it out ${ }^{7}$. A consumer counter-culture has therefore grown, combined with organic status, one can see it making a significant come-back in years to come. It is claimed to have potential health benefits. The United States Department of Agriculture, for instance, has published an analysis of milk samples taken in 2013 from 14 commercial processors from seven regions throughout the United States. This showed that, averaged over a year, organic milk contained 25\% less omega 6 fatty acids (bad cholesterol) and $62 \%$ more omega 3 fatty acids than conventional milk, leading to a favourable ratio between them of 2.2, compared to 5.7 in conventional milk.

\section{CONCLUSION}

So what then is milk quality? Medieval and early modern concerns about short measure were replaced in the nineteenth century by adulteration. Quality then became the sale of foods such as drinking-milk in their "natural" form, without any form of manipulation or intervention. This was extended to avoiding any misrepresentation in descriptions or the falsification of marketing claims. Laws were passed criminalising food frauds and towards the end of the nineteenth century the sciences of physics and organic chemistry provided the means of prosecuting traders of foods who deviated from a collectively agreed norm of composition.

The twentieth century added greater complexity of quality thinking. In the paper we identified hygiene, sanitation and infectious disease as an important dimension. These were a continuation of concerns from earlier periods, to which was added the new insight that certain foods, even in their natural state, might cause illness and death through the presence of substances dangerous in excess. Drinking-milk was an example because of the presence of butter fat.

We then went on to discuss the factors that have affected the compositional characteristics of milk. First, cattle breeding was a legal means of altering the constituents of milk

7. This was no longer possible in Scotland from 1983, when all unpasteurized drinking-milk was banned. 
over a long period, with economic consequences. Second, a variety of technologies were important, including means of extending the shelf life of milk (cooling, pasteurization), and of improving its bacteriological quality (pasteurization). Third, these were elements of the re-organization of the milk trade along capitalist lines in order to bring large quantities to the urban markets, along with state-sponsored systems of quality monitoring and attempts to provide quality information to the consumer through officially-approved grades. Fourth, the quality-enhancement efforts of the state, the private sector and the monopolistic marketing boards were supported by laws against food fraud and the common law of contracts.

It was really only in the second half of the twentieth century that levels of trust among British consumers rose to the point where they began to purchase significantly more drinking-milk. Adulteration had gone, the risk of disease had diminished, and even the link between butter fat and heart disease was diminished as a threat by the introduction of lowfat milk. What has mattered increasingly has been the quality segmentation of the drinking-milk market. Taste has come increasingly to the fore, for instance with the provision of flavoured milks. There has also been greater modification of composition, including the recognition at last that even lactose-intolerant and allergic consumers can participate in specially tailored niche markets.

In conclusion, we can say that quality is a multi-faceted concept. Much of the literature is from business management (Grunert, 2005) but I have tried to show in this paper that the idea quality also has potential for historical analysis. It is a dynamic concept which can never be tied to any one time or place and which must be thought of as having a genealogy, a biography, a career.

\section{ACKNOWLEDGEMENTS}

My thanks are due to Professor Fernando Collantes for suggesting this article and to the reviewers and editorial team of Historia Agraria for facilitating it.

\section{REFERENCES}

ATKINs, P. J. (1977). The Intra-Urban Milk Supply of London, circa 1790-1914. Transactions of the Institute of British Geographers, new series, 2 (3), 383-99.

AtKINs, P. J. (1978). The Growth of London's Railway Milk Trade, c. 1845-1914. Fournal of Transport History, new series, (4), 208-26. 
AtKIns, P. J. (1980). The Retail Milk Trade in London, c. 1790-1914. Economic History Review, 2nd series, 33 (4), 522-37.

AtKINs, P. J. (1984). Sir George Barham (1836-1913) Milk Wholesaler and Retailer. In D. J. Jeremy (Ed.), Dictionary of Business Biography (pp. 157-61). Vol. 1. London: Butterworths.

AtKINS, P. J. (1991). Sophistication detected: Or, the Adulteration of the Milk Supply, 1850-1914. Social History, 16 (3), 317-39.

AtKINs, P. J. (1992). White Poison?: The Health Consequences of Milk Consumption, 1850-1930. Social History of Medicine, 5 (2), 207-27.

AtKIns, P. J. (2000a). Milk Consumption and Tuberculosis in Britain, 1850-1950. In A. FEnton (Ed.), Order and Disorder: The Health Implications of Eating and Drinking in the Nineteenth and Twentieth Centuries (pp. 83-95). East Linton: Tuckwell Press. Atkins, P. J. (2000b). The Pasteurization of England: The Science, Culture and Health Implications of Milk Processing, 1900-1950. In D. F. SMITH \& J. PHILLIPS (Eds.), Food, Science, Policy and Regulation in the Twentieth Century: International and Comparative Perspectives. London: Routledge.

Atkins, P. J. (2003). Mother's Milk and Infant Death in Britain, circa 1900-1940. Anthropology of Food, (2). http://aof.revues.org/document310.html

AtKINs, P. J. (2005). Fattening Children or Fattening Farmers?: School Milk in Britain, 1900-1950. Economic History Review, (58), 57-78.

Atkins, P. J. (2007a). Laboratories, Laws and the Career of a Commodity. Environment and Planning D: Society and Space, 25 (6), 967-89.

ATKINS, P. J. (2007b). Le concept de lait sain en Grande-Bretagne et sa mise en oeuvre, 1900-1960. In F. AudoIn-RouZEAU \& F. SABBAN (Eds.), Un aliment sain dans un corps sain: Perspectives historiques (pp. 273-87). Tours: Presses Universitaires François-Rabelais.

AtKins, P. J. (2008). Fear of Animal Foods: A Century of Zoonotics. Appetite, 51 (1), 1821.

Atkins, P. J. (2010). Liquid Materialities: A History of Milk, Science and the Law. Farnham: Ashgate.

Atkins, P. J. (2011). The Material Histories of Food Quality and Composition. Endeavour, 35 (2-3), 74-9.

AtKIns, P. J. (2013). A Social History of the Science of Food Analysis and the Control of Adulteration. In A. MurcotT, W. Belasco \& P. Jackson (Eds.), The Handbook of Food Research (pp. 97-108). London: Bloomsbury.

AtKIns, P. J. (2016). A History of Uncertainty: Bovine Tuberculosis in Britain, 1850 to the Present. Winchester: Winchester University Press.

AtKINs, P. J. (forthcoming 2017). Infant Feeding and Infant Mortality in the Late Nineteenth and Early Twentieth Centuries. 
BARRuel, M. (1829). Considérations hygiéniques sur le lait vendu à Paris comme substance alimentaire. Annales d'hygiène publique et de médecine légale, (1), 404-19.

Boppanna, N. (2007). Evaluating the Difference between Organic Milk and Cheese and Inorganic Milk and Cheese based on Sensory Perception. MSc Thesis. Menomonie: University of Wisconsin.

British Friesian Cattle Society (1930). History of British Friesian Cattle, their Performance, their Pedigrees, and History of the British Friesian Cattle Society 1909 to 1930. Lewes: BFCS.

Callon, M., Méadel, C. \& Rabeharisoa, V. (2002). The Economy of Qualities. Economy and Society, 31 (2), 194-217.

Cameron Brown, C. A. (1936). Refrigeration for the Farm and Dairy. Oxford: Oxford University Press.

Clayton, E. G. (1899). Note on Boric Acid in Milk samples. Analyst, (24), 141b-142.

Cook, T.W. (1960). Interdepartmental Committee on Milk Composition in the United Kingdom. British Parliamentary Papers, Cmnd 1147.

DeLÉPINE, S. (1910). Report to the Local Government Board on Investigations in the Public Health Laboratory of the University of Manchester upon the Prevalence and Sources of Tubercle Bacilli in Cow's Milk, Appendix B, no. 5. Annual Report of Medical Officer of Health to the Local Government Board for 1908-9. British Parliamentary Papers, (Cd. 4935), XXVIII, 777-880.

Ford, H. (1923). My Life and Work. Garden City: Doubleday.

FRANKLIN, R. (1953). Ministry of Agriculture: Report of the Working Party on Quality Milk Production. London: Her Majesty's Stationery Office.

Grunert, K. G. (2005). Food Quality and Safety: Consumer Perception and Demand. European Review of Agricultural Economics, 32 (3), 369-91.

HARris, A. E. (1899). Forty-Fourth Annual Report on the Health and Sanitary Condition of the Parish of St Mary, Islington, 1899. London:Vail \& Co.

Hickey, M. (2009). Current Legislation of Market Milks. In A. Y. TAMIME (Ed.), Milk Processing and Quality Management (pp. 101-38). Chichester:Wiley-Blackwell.

KirChHelle, C. (2016). Toxic Confusion:The Dilemma of Antibiotic Regulation in West German Food Production (1951-1990). Endeavour, 40 (2), 114-27.

MackenzIE, L. (1922). Inter-Departmental Committee on the Laws, Regulations and Procedure Governing the Sale of Milk in Scotland. British Parliamentary Papers, (Cmd. 1749), II, 835-961.

Maxwell, H. (1902). Report of the Departmental Committee into the Use of Preservatives and Colouring Matters in the Preservation and Colouring of Food. British Parliamentary Papers, (Cd. 833), XXXIV, 579.

Mintel (2014). Dairy Drinks, Milk and Cream-UK-April 2014. London: Mintel. 
O'NeIll, J. (2015). Antimicrobials in Agriculture and the Environment: Reducing Unnecessary Use and Waste: The Review on Antimicrobial Resistance. London: Wellcome Trust.

Podolsky, S. H. (2014). The Antibiotic Era: Reform, Resistance, and the Pursuit of a Rational Therapeutics. Baltimore: Johns Hopkins University Press.

StANFORD, J. K. (1956). British Friesians: A History of the Breed. London: Max Parrish.

Sumner, J. (2010). Progress in Mastitis Control. In The Dairy Group (Eds.), Proceedings of the 22nd British Mastitis Conference (pp. 1-12). Nottingham: University of Nottingham.

Vissers, M. M. M. \& Driehuis, F. (2009). On-Farm Hygienic Milk Production. In A. Y. TAmime (Ed.), Milk Processing and Quality Management (pp. 1-22). Chichester: Wiley-Blackwell.

WAdDIngton, K. (2005). The Bovine Scourge: Meat, Tuberculosis and the Public's Health, 1850-1914. Woodbridge: Boydell. 